\title{
Twenty years of research on spent nuclear fuel in the context of final disposal at KIT-INE in multinational collaborative projects
}

\author{
Michel Herm, Elke Bohnert, Luis Iglesias Pérez, Tobias König, Volker Metz, Arndt Walschburger, and \\ Horst Geckeis \\ Institute for Nuclear Waste Disposal (INE), Karlsruhe Institute of Technology (KIT), \\ P.O. Box 3640, 76021 Karlsruhe, Germany
}

Correspondence: Michel Herm (michel.herm@kit.edu)

Published: 10 November 2021

\begin{abstract}
Disposal of spent nuclear fuel (SNF) in deep geological repositories is considered a preferential option for the management of such wastes in many countries with nuclear power plants. With the aim to permanently and safely isolate the radionuclide inventory from the biosphere for a sufficient time, a multibarrier system consisting of technical, geotechnical and geological barriers is interposed between the emplaced waste and the environment. In safety assessments for deep underground repositories, access of water, followed by failure of canisters and finally loss of the cladding integrity is considered in the long-term. Hence, evaluating the performance of SNF in deep geological disposal systems requires process understanding of SNF dissolution and rates as well as quantification of radionuclides release from SNF under reducing conditions of a breached container. In order to derive a radionuclide source term, the SNF dissolution and alteration processes can be assigned to two steps: (i) instantaneous release of radionuclides upon cladding failure from gap and grain boundaries and (ii) a long-term release that results from dissolution of the fuel grains itself (Ewing, 2015).

In this context, research at KIT-INE has focused for more than 20 years on the behavior of SNF (irradiated $\mathrm{UO}_{2}$ and MOX fuels) under geochemical conditions ( $\mathrm{pH}$, redox and ionic strength) representative of various repository concepts, including the interaction of SNF with backfill material, such as bentonite as well as the influence of iron corrosion products, e.g. magnetite and radiolytic reactions on SNF dissolution mechanisms. Since 2001, KIT-INE has contributed with experimental and theoretical studies on the behavior of SNF under repository relevant conditions to six Euratom projects viz SFS (2001-2004), NF-PRO (2004-2006), MICADO (2006-2009), RECOSY (2007-2011), FIRST-Nuclides (2012-2014) and DISCO (2016-2021). Moreover, since 2007, overall 4 consecutive projects for the Belgian waste management organization, ONDRAF-NIRAS, were performed on the behavior of SNF under conditions representative of the Belgian "Supercontainer" concept.

In this contribution, we summarize major achievements of theses research projects to understand and quantify the radionuclide release from dissolving SNF under repository conditions. In particular, the dependence of radionuclide release on the chemical composition of the aqueous and gaseous phase in the proximity of repositories in different types of host rock is discussed.
\end{abstract}

Kurzfassung. Die Entsorgung von abgebranntem Kernbrennstoff (,spent nuclear fuel“, SNF) in geologischen Tiefenlagern wird in vielen Ländern mit Kernkraftwerken als bevorzugte Option für die Entsorgung dieser Abfälle angesehen. Um das Radionuklidinventar dauerhaft und sicher von der Biosphäre zu isolieren, wird ein Mehrfachbarrierensystem aus technischen, geotechnischen und geologischen Barrieren zwischen den eingelagerten Abfällen und der Umwelt errichtet. Bei der Sicherheitsbewertung von unterirdischen Endlagern wird der Zugang von Wasser, gefolgt vom Versagen der Behälter und schließlich dem Verlust der Integrität der Umhüllung auf lange Sicht berücksichtigt. Daher erfordert die Bewertung des Verhaltens von SNF in tiefen geologischen Endlagern ein Prozessverständnis der SNF-Auflösung und -Raten sowie eine Quantifizierung der 
Radionuklidfreisetzung aus SNF unter reduzierenden Bedingungen eines durchbrochenen Behälters. Um einen Radionuklidquellenterm abzuleiten, können die SNF-Auflösungs- und Veränderungsprozesse zwei Schritten zugeordnet werden: (i) eine sofortige Freisetzung von Radionukliden bei Hüllenbruch aus Spalt- und Korngrenzen und (ii) eine langfristige Freisetzung, die aus der Auflösung der Brennstoffkörner selbst resultiert (Ewing, 2015).

In diesem Zusammenhang konzentriert sich die Forschung am KIT-INE seit mehr als 20 Jahren auf das Verhalten von SNF (bestrahlte $\mathrm{UO}_{2}$ - und MOX-Brennstoffe) unter geochemischen Bedingungen (pH-Wert, Redox und Ionenstärke), die für verschiedene Endlagerkonzepte repräsentativ sind, einschließlich der Wechselwirkung von SNF mit Versatzmaterial wie Bentonit sowie des Einflusses von Eisenkorrosionsprodukten, z. B. Magnetit, und radiolytischen Reaktionen auf SNF-Auflösungsmechanismen. Seit 2001 hat das KIT-INE mit experimentellen und theoretischen Studien zum Verhalten von SNF unter endlagerrelevanten Bedingungen zu sechs EuratomProjekten beigetragen, nämlich SFS (2001-2004), NF-PRO (2004-2006), MICADO (2006-2009), RECOSY (2007-2011), FIRST-Nuclides (2012-2014) und DISCO (2016-2021). Darüber hinaus wurden seit 2007 vier aufeinanderfolgende Projekte für die belgische Abfallentsorgungsorganisation ONDRAF-NIRAS zum Verhalten von SNF unter Bedingungen durchgeführt, die für das belgische „Supercontainer“-Konzept repräsentativ sind.

In diesem Beitrag fassen wir die wichtigsten Ergebnisse dieser Forschungsprojekte zusammen, um die Quantifizierung der Radionuklidfreisetzung aus sich auflösenden SNF unter Endlagerbedingungen zu verstehen. Insbesondere wird die Abhängigkeit der Radionuklidfreisetzung von der chemischen Zusammensetzung der wässrigen und gasförmigen Phase im Nahfeld von Endlagern in verschiedenen Arten von Wirtsgesteinen diskutiert.

Acknowledgements. The authors would like to thank our (former) colleagues at KIT-INE, in particular to Kathy Dardenne, Ernesto González-Robles, Bernd Grambow, Manfred Kelm, Bernhard Kienzler, Andreas Loida, Mara Marchetti, Nikolaus Müller, Markus Plaschke, Jörg Rothe and Dieter Schild for their significant contributions to the research on spent nuclear fuel behavior at KITINE.

\section{References}

Ewing, R. C.: Long-term storage of spent nuclear fuel, Nature Materials, 14, 252-257, https://doi.org/10.1038/nmat4226, 2015. 